\title{
Factors Affecting Dairy Farmers' Application of Agricultural Innovations: A Case Study from Muğla Province
}

\section{Tayfun Çukur*}

Department of Marketing and Advertising, Milas Vocational School, Muğla Sitkı Kocman University, 48200 Milas/Muğla, Turkey

\section{A R T I C L E I N F O}

\section{Article history:}

Received 29 March 2016

Accepted 14 June 2016

Available online, ISSN: 2148-127X

\section{Keywords:}

Innovation

Dairy farm

Multinominal logit

Milas

Information \begin{abstract}
A B S T R A C T
The main objective of this study is to determine the factors affecting the application of innovations for dairy farmers in the Milas district, Muğla province, Turkey. Data from 71 dairy farmers and the Multinominal logit model are used for this study. The dependent variable of the model is divided into three categories; "I don't apply any agricultural innovations", "I apply agricultural innovations only after other farmers apply and express their positive opinion" and "I apply agricultural innovations". In conclusion of the analysis, the comparisons are done with the farmers who "do not apply any agricultural innovations," and the farmers who "apply agricultural innovations only after other farmers apply and express their positive opinion"; it is determined that a one unit increase in educational level raised the likelihood of applying innovations after receiving positive opinion. When the farmers that "apply agricultural innovation", and that "apply agricultural innovations only after other farmers apply and express their positive opinion" are compared, it is found that a one unit increase in the number of milking animals had increased the likelihood of applying the innovations.
\end{abstract}

${ }^{*}$ Corresponding Author:

E-mail: tayfunc@mu.edu.tr

\section{Introduction}

A simple definition of innovation is the application of technical, organizational, or other forms of knowledge to achieve positive novel changes in a particular situation (Snapp and Pound, 2008). Agricultural innovation is an organizational phenomenon influenced by individual and collective behaviours, capabilities for innovation and enabling conditions (World Bank, 2011). Agricultural innovation is a socially constructed process. Innovation is the result of the interaction of a multitude of agents and stakeholders. If agricultural research and extension are important to agricultural innovation, so are markets, systems of government, social norms, and, in general, a host of factors that create the incentives for a farmer to decide to change the way in which he or she works, and that rewards or frustrates his or her decision (Anandajayasekeram, et al., 2009).

Adoption of agricultural production technologies in developing countries is influenced by a wide range of economic and social factors as well as physical and technical aspects of farming and the risk attitude of farmers. It is important to understand the role of these factors to ensure the development of appropriate technologies and the design of successful development projects (Kebede et al., 1990).
In a study done in the East Mediterranean region of Turkey, a statistically meaningful relationship is found between the age of farmers, income level, investment and owning improved breeds of animals; and the innovation adoption of dairy farmers (Boz et al., 2011).

In research done in the Erzurum province of Turkey, a statistically meaningful relationship was found between education status, animal breed and subsidy benefits; and the innovation adoption of dairy farmers (Aksoy et al., 2011).

In research regarding socio-economic factors affecting adoption of agricultural innovations in dairy farming farms in the Afyonkarahisar province of Turkey, a meaningful relationship was detected between the scale of the farms, education level and age of the farmer, his work experience, his standard of living, his participation in social life, his level of being open to outer cultures, his ability of empathy and his level of using mass media tools; and adoption of innovations (Çiçek et al., 2008).

In research done in India, a meaningful relationship was found between age, education, extension contact, annual income, operational land holding, innovation proneness and decision making ability of the respondents; and adoption of advanced dairy farming implementations 
of the farmers that do dairy farming (Singha and Baruah, 2012).

In research analysing effective factors of adoption of dairy farming technologies of rural women in India, a statistically meaningful relationship was found between the adoption of technologies; and education, social participation, economic motivation, personal locality, personal cosmopolite, milk marketing channel, veterinary health camps, feed $\&$ fodder incentive, extension support, awareness, knowledge, attitude (Halakatti et al., 2007).

In research analysing the effective factors in adoption of artificial insemination technologies by dairy farmers in Uganda, a statistically meaningful relationship was found between the adoption of technology; and age of the farmer, years of awareness of AI technology, total farm milk production and sales, extension visits per year, and quality of AI services provided to the farmers (Kaaya et al., 2005).

In research analysing the effective factors in the adoption of dairy technologies of the farmers that do dairy farming in Ethiopia, a statistically meaningful relationship was found between the adoption of technology; and family size, farming experience, availability of dairy production extension services, availability of cross breed cows, accessibility of savings institutions, total income from milk and milk products, availability of training on livestock, age of household head and off-farm activity participation (Dehinenet et al., 2014).

A statistically meaningful relationship was found between the adoption of innovations of dairy farmers in Malawi; and the number of extension visits and milk yield (Tebug et al., 2012).

According to Akudugu et al. (2012) farm size, the expected benefits of adopting new technology, access to credit and extension services are the factors that significantly influence technology adoption decisions of farm households related to this subject.

In research analysing the effective factors in the adoption of scientific dairy farming of dairy farmers in Tamil Nadu, a statistically meaningful relationship was found between scientific dairy farming; and education status, herd size, frequency of contact, information utilization patterns and information seeking behaviour (Jaisridhar et al., 2013).

In research analysing the effective factors in the adoption of dairy technologies of the dairy farmers in Ethiopia, a statistically meaningful relationship was found between the innovation adoption of farmers; and owning agricultural land and using credit (Amlaku et al., 2012).

When the literature was reviewed, it was observed that effective factors of the adoption of specific agricultural innovations were analysed in the previous studies. This study discusses the idea of agricultural innovation as a whole and has tried to determine the viewpoint of farmers about agricultural innovation; instead of discussing agricultural innovations separately.

The objective of this study was to determine the factors affecting the application of innovations in dairy farms in the district of Milas.

\section{Materials and Methods}

The main material of this study was the data collected through face-to-face surveys with the farmers who were members of the Milas Milk Producers Union. 2397 farmers that were members of Milas Milk Producers Union constituted the population of this study (Anonymous, 2014). In this study, the farmers that were conferred were selected by the proportional sampling method (Newbold, 1995). The study was grounded on $90 \%$ significance level and $10 \%$ error margin. The data belongs to July-August period of 2014. 12 neighbourhoods (villages) of the district were included in this study.

$$
n=\frac{N p(1-p)}{(N-1) \sigma_{p x^{2}}+p(1-p)}
$$

In this equation;

n : Sample size

$\mathrm{N}$ : Population

$\mathrm{p}$ : Taken as 0.50 in order to reach maximum sample size

$(1-p): 0.5$

$\sigma_{p x}^{2}:$ Variance

As a result of this calculation the total number of farmers to be interviewed was calculated as 66. In this study, 5 producers were also subjected to a reserved survey and a total of 71 surveys were evaluated. While distributing the producers to villages, proportional representation was used.

The multinomial (polytomous) logistic regression model is a simple extension of the binomial logistic regression model. It is used when the dependent variable has more than two nominal or unordered categories, in which dummy coding of independent variables is quite common (Bayaga, 2010).

The model in (1) is a multinominal logit model. The estimated equations provide a set of probabilities for the $J$ +1 choice for a decision maker with characteristics $x i$. Before proceeding, we must remove indeterminacy in the model. If we define $\beta^{*}{ }_{j}=\beta j+\mathrm{q}$ for any vector $\mathrm{q}$, then recomputing the probabilities defined below using $\beta^{*}{ }_{j}$ instead of $\beta j$ produces the identical set of probabilities because all the terms involving q drop out. A convenient normalization that solves the problem is $\beta_{0}=0$ (Greene, 2002).

$$
\operatorname{Prob}\left(Y_{i}=j\right)=\frac{e^{\beta^{\prime}{ }^{x_{i}}}}{\sum_{k=0}^{4} e^{\beta^{\prime} x_{i}}}, \cdots j=0,1, \cdots, 4
$$

In this study, the factors affecting the applications of agricultural innovations by member farmers of the Milas Milk Producers Union in the Milas district of Muğla Province, were analysed by utilization of multinominal logistic regression analysis. For this purpose, farmers' application options of agricultural innovations ("not applying any agricultural innovations", "applying 
agricultural innovations only after other farmers apply and express their positive opinion", and "applying agricultural innovations") was chosen to be the dependent variable of the model. The independent variables of the model are presented in Table 1. In the model "applying agricultural innovations only after other farmers apply and express their positive opinion" is taken as the reference group. Therefore other categories ("not applying any agricultural innovations" and "applying agricultural innovations") are analysed according to the reference.

\section{Results and Discussion}

\section{The Farmer Characteristics}

The average age of the farmers in this study was 53.61 and their average years of education were 5.83 years. $95.8 \%$ of them were married and $4.2 \%$ of them were single. All of the selected farmers in this study were male. 93\% of the farmers also have crop production and $7 \%$ of them only have dairy farming activity. $45.1 \%$ of the farmers were members of cooperatives; $54.9 \%$ of them were not a member of any cooperative. During the last five year period, $69 \%$ of the producers used credit, while $31 \%$ of the producers did not use credit. The farmers' average agricultural experience was 30.85 years. $39.45 \%$ of the farmers also had non-agricultural income. Besides their agricultural activities, these farmers also performed in professions such as butcher, grocer, taxi driver and hotel worker etc.

\section{Farm Characteristics}

The average dairy farming experience is 28.42 years. The distance of the farms to Milas district centre was 16.53 kilometers on average. While $60.6 \%$ of the enterprises performed both beef cattle farming and dairy farming, 39.4\% performed only dairy farming. 38\% of the farmers considered expanding their farm, whereas $62 \%$ of them did not consider growing their farm. It was determined that the average number of cows milked on the farms was 4.95 and the daily milk production averaged 80.11 litres.

Table 1 Definition of the variables.

\begin{tabular}{|c|c|c|c|}
\hline Variables & Name of variable & $\mathrm{n}$ & $\%$ \\
\hline \multicolumn{4}{|c|}{ Dependent variables } \\
\hline $\mathrm{YO}$ & I don't apply any agricultural innovations & 8 & 11.3 \\
\hline Y1 & $\begin{array}{l}\text { I apply agricultural innovations only if after other farmers apply and explain } \\
\text { their positive opinion }\end{array}$ & 34 & 47.9 \\
\hline $\mathrm{Y} 2$ & I apply agricultural innovations & 29 & 40.8 \\
\hline \multicolumn{4}{|c|}{ Independent variables } \\
\hline AGE & $\begin{array}{l}1 \text { if dairy farmers age is }<40 \\
\text { zero otherwise }\end{array}$ & $\begin{array}{c}7 \\
64\end{array}$ & $\begin{array}{r}9.9 \\
90.1\end{array}$ \\
\hline EDU & $\begin{array}{l}0 \text { if dairy farmers have primary school degree or less, } \\
1 \text { more educated }\end{array}$ & $\begin{array}{l}58 \\
13\end{array}$ & $\begin{array}{l}81.7 \\
18.3\end{array}$ \\
\hline EXPE & $\begin{array}{l}1 \text { if experience of dairy farming is }>20 \text { year } \\
\text { zero otherwise }\end{array}$ & $\begin{array}{l}46 \\
25\end{array}$ & $\begin{array}{l}64.8 \\
35.2\end{array}$ \\
\hline ANIM & $\begin{array}{l}1 \text { if number of cows milked are }>4 \\
\text { zero otherwise }\end{array}$ & $\begin{array}{l}25 \\
46\end{array}$ & $\begin{array}{l}35.2 \\
64.8\end{array}$ \\
\hline MILK & $\begin{array}{l}1 \text { if daily milk production in the farms are }>99 \text { litres } \\
\text { zero otherwise }\end{array}$ & $\begin{array}{l}16 \\
55\end{array}$ & $\begin{array}{l}22.5 \\
77.5\end{array}$ \\
\hline REC & $\begin{array}{l}1 \text { if dairy farmers keep farm records regularly } \\
\text { zero otherwise }\end{array}$ & $\begin{array}{l}20 \\
51\end{array}$ & $\begin{array}{l}28.2 \\
71.8\end{array}$ \\
\hline $\mathrm{MACH}$ & $\begin{array}{l}1 \text { if farmers use milking machine } \\
\text { zero otherwise }\end{array}$ & $\begin{array}{l}60 \\
11\end{array}$ & $\begin{array}{l}84.5 \\
15.5\end{array}$ \\
\hline FORA & $\begin{array}{l}1 \text { if farmers cultivate forage crops } \\
\text { zero otherwise }\end{array}$ & $\begin{array}{l}58 \\
13\end{array}$ & $\begin{array}{l}81.7 \\
18.3\end{array}$ \\
\hline SILA & $\begin{array}{l}1 \text { if farmers cultivate silage crops } \\
\text { zero otherwise }\end{array}$ & $\begin{array}{l}56 \\
15\end{array}$ & $\begin{array}{l}78.9 \\
21.1\end{array}$ \\
\hline COOP & $\begin{array}{l}1 \text { if dairy farmers is cooperative member } \\
\text { zero otherwise }\end{array}$ & $\begin{array}{l}32 \\
39\end{array}$ & $\begin{array}{l}45.1 \\
54.9\end{array}$ \\
\hline MILA & $\begin{array}{l}1 \text { if dairy farmers go to Milas district frequently } \\
\text { zero otherwise }\end{array}$ & $\begin{array}{l}38 \\
33 \\
\end{array}$ & $\begin{array}{l}53.5 \\
46.5\end{array}$ \\
\hline BEEF & $\begin{array}{l}1 \text { if farmers do beef cattle farming } \\
\text { zero otherwise }\end{array}$ & $\begin{array}{l}43 \\
28\end{array}$ & $\begin{array}{l}60.6 \\
39.4\end{array}$ \\
\hline INCO & $\begin{array}{l}1 \text { if farmers have non-agricultural income } \\
\text { zero otherwise }\end{array}$ & $\begin{array}{l}28 \\
43\end{array}$ & $\begin{array}{l}39.4 \\
60.6\end{array}$ \\
\hline AGRI & $\begin{array}{l}1 \text { if farmers want to carry on agricultural activities } \\
\text { zero otherwise }\end{array}$ & $\begin{array}{l}50 \\
21\end{array}$ & $\begin{array}{l}70.4 \\
29.6\end{array}$ \\
\hline
\end{tabular}


It was determined that $28.2 \%$ of the farmers keep their farm records regularly. It was found that the farmers were not interested in livestock insurance. Namely, it was observed that only $4.2 \%$ of the farmers included in this study had their cows insured. It was identified that the cows in all of the farms had numbered ears. It was determined that $85 \%$ of the farmers used milking machines. The percentage of the farmers that produced maize for silage was found to be $78.9 \%$. $81.7 \%$ of the farmers produced forage crops.

\section{Information Resources of Farmers}

The information resources of the farmers regarding animal breeding, animal health, milk marketing and herd management is shown in Table 2. 59.15\% of the farmers relied on their own experiences on issues related to animal breeding. It was identified that $26.76 \%$ of the farmers consulted veterinarians on issues related to animal breeding. $87.32 \%$ of them consulted veterinarians regarding animal health issues. Conversely, $15.49 \%$ of the farmers relied on their own experiences on issues related to animal health. While $46.5 \%$ of the farmers acted upon their experiences about milk marketing, $43.7 \%$ of them consulted the Milas Milk Producers Union. 87.32\% of the farmers abided by their experiences on issues related to herd management, whereas $12.68 \%$ of them consulted their friends and relatives.

\section{Cosmopoliteness}

Contact with the world outside the village and especially urban centers links the farmer with the larger society, which has a positive influence on his level of consciousness and outlook (Shahin, 2004). For this reason, farmers' travelling frequency to the district (Milas) and Province (Muğla) was examined. 53.5\% of the farmers included in the survey travelled to the district frequently, $38 \%$ of them travelled to the district occasionally and $8.5 \%$ of them travelled to the district rarely. On the other hand, $1.4 \%$ of the farmers travelled to the province frequently, $12.7 \%$ of them travelled to the province occasionally and $85.9 \%$ of them travelled to the province rarely. Agriculture fairs may be important for the farmers for reasons such as getting out of the environment they live in as well as obtaining information about new agricultural technologies. When the farmers' participation status for the agriculture fairs that took place in the Milas district were examined it was determined that $88.7 \%$ of the farmers attended the agriculture fairs.

\section{Econometric Results}

A summary of the multinominal logistic model estimates of the determinants of application of agricultural innovations among dairy farmers is presented in Table 3. The likelihood ratio tests show that the model is statistically meaningful. The chi-square likelihood of the model is below 0.05 ratio (0.005). Cox \& Snell $\mathrm{R}$ Square and the Nagelkerke $\mathrm{R}$ square value, they provide an indication of the amount of variation in the dependent variable. These are described as pseudo $\mathrm{R}$ square (Bayaga, 2010). The distribution in Table 3 below reveals that the values are 0.512 and 0.600 respectively; suggesting that between $51.2 \%$ percent and $60.0 \%$ percent of the variability is explained by this set of variables used in the model.

Table 2 Information resources of farmers

\begin{tabular}{lcc}
\hline Information resources of farmers about animal breeding* & $\mathrm{n}=71$ & Farmer $(\%)$ \\
\hline Their own experiences & 42 & 59.15 \\
Friends and relatives & 4 & 5.63 \\
District Directorate of Food Agriculture and Livestock & 1 & 1.41 \\
Milas Milk Producers Union & 9 & 12.68 \\
Veterinary & 19 & 26.76 \\
Animal feed firms & 8 & 11.27 \\
Television & 2 & 2.82 \\
\hline Information resources of farmers about animal health* & & 15.49 \\
\hline Their own experiences & 11 & 1.41 \\
Friends and relatives & 1 & 2.82 \\
Milas Milk Producers Union & 2 & 87.32 \\
Veterinary & 62 & 2.82 \\
Animal feed firms & 2 & 46.5 \\
\hline Information resources of farmers about milk marketing & & 7.0 \\
\hline Their own experiences & 33 & 43.7 \\
Friends and relatives & 5 & 2.8 \\
Milas Milk Producers Union & 31 & 87.32 \\
Veterinary & 2 & 12.68 \\
\hline Information resources of farmers about herd management* & & 1.41 \\
\hline Their own experiences & 62 & 1.41 \\
Friends and relatives & 9 & 1.41 \\
District Directorate of Food Agriculture and Livestock & 1 & 1 \\
Veterinary & 1 & \\
Animal feed firms & & \\
\hline
\end{tabular}

\footnotetext{
*More than $100 \%$ due to multiple answers
} 
Table 3 Multinominal Logistic regression Results

\begin{tabular}{|c|c|c|c|c|}
\hline \multirow{2}{*}{ Model } & \multirow{2}{*}{$\begin{array}{l}\text { Model Fitting Criteria } \\
-2 \text { Log Likelihood }\end{array}$} & \multicolumn{3}{|c|}{ Likelihood Ratio Tests } \\
\hline & & Chi-Square & $\mathrm{df}$ & Sig. \\
\hline Intercept Only & 134.161 & & & \\
\hline Final & 83.161 & 51.000 & 28 & 0.005 \\
\hline \multicolumn{5}{|c|}{ Cox and Snell 0.512 Nagelkerke 0.600 McFadden 0.372 Likelihood Ratio Tests } \\
\hline \multirow{2}{*}{ Model } & Model Fitting Criteria & \multicolumn{3}{|c|}{ Likelihood Ratio Tests } \\
\hline & -2 Log Likelihood & Chi-Square & $\mathrm{df}$ & Sig. \\
\hline Intercept & $83.161^{\mathrm{a}}$ & 0.000 & 0 & \\
\hline AGE & 85.710 & 2.549 & 2 & 0.280 \\
\hline EDU & 90.240 & 7.079 & 2 & $0.029 * *$ \\
\hline EXPE & 90.536 & 7.375 & 2 & $0.025 * *$ \\
\hline ANIM & 88.219 & 5.058 & 2 & $0.080 * * *$ \\
\hline MILK & 89.018 & 5.857 & 2 & $0.053 * * *$ \\
\hline REC & 83.735 & 0.574 & 2 & 0.750 \\
\hline $\mathrm{MACH}$ & 89.850 & 6.689 & 2 & $0.035 * *$ \\
\hline FORA & 89.701 & 6.540 & 2 & $0.038 * *$ \\
\hline SILA & 99.562 & 16.401 & 2 & $0.000 *$ \\
\hline COOP & 85.042 & 1.881 & 2 & 0.390 \\
\hline MILA & 84.457 & 1.296 & 2 & 0.523 \\
\hline BEEF & 97.848 & 14.687 & 2 & $0.001 *$ \\
\hline INCO & 96.289 & 13.128 & 2 & $0.001 *$ \\
\hline AGRI & 87.938 & 4.777 & 2 & $0.092 * * *$ \\
\hline
\end{tabular}

* Significant at $\mathrm{P}<0.01 * *$ Significant at $\mathrm{P}<0.05 \quad$ *** Significant at $\mathrm{P}<0.10$

When the farmers that "do not apply agricultural innovation" and that "apply agricultural innovations only after other farmers apply and express their positive opinion" were compared, a one unit increase in education level increased the possibility of "applying agricultural innovations only after other farmers apply and express their positive opinion". Education level is an important factor in determining farmers' willingness to adopt innovation; there are a large number of studies showing that there is a meaningful relationship between the education level and adoption of innovation (Howley et al., 2012; Prokopy et al., 2008; Mishra et al., 2009; Khanal and Gillespie, 2013; Quddus, 2012). It was identified that, having non-agricultural income, milking machine usage, silage production and beef cattle farming activity have a positive effect on the farmers that do not apply agricultural innovation. Nominately, the farmers that do not do silage production have the likelihood of applying innovation 8 times more than the farmers that do silage production. Farmers who have no income other than agriculture have the likelihood of applying innovations 1.9 times more than farmers who have non-agricultural incomes (Table 4).

When the farmers that "apply agricultural innovation" and that "apply agricultural innovations only after other farmers apply and express their positive opinion" were compared, it was found that a one unit increase in number of milking animals raised the likelihood of applying the innovations. A one unit increase in number of milking animals raised the likelihood of applying innovations 6fold (Table 4). When the literature is reviewed, it is specified in plenty of studies that there is a meaningful relationship between number of milking animals/herd size and adoption of agricultural innovations. Some of these studies are as follows (Letha, 2013; Jera and Ajayi, 2008).

On the other hand, a one unit increase in dairy milk production raised the likelihood of adoption of innovation after positive opinion. When literature is reviewed, it is stated in studies that there is a meaningful relation between dairy milk production and adoption of agricultural innovations (Mburu et al., 2007; Kaaya et al., 2005). It is determined that producing fodder crops and beef cattle farming has a positive effect on applying innovations.

The selected farmers in this study are small scaled farms. The number of cows milked per farm was around 4.95 and the average daily milk production of these farms was approximately $80.11 \mathrm{kgs}$. It was found that the daily milk yield per animal was $16.18 \mathrm{~kg} / \mathrm{animal}$. Farmers milk the cows twice a day, once in the morning and once in the evening. Farmers, sell the milk to Milas Milk Producers Union. One way to increase the agricultural production for the small scaled farms is to increase the agricultural efficiency. Undoubtedly, the adoption and application of modern agriculture technologies will have a positive effect on the increase of agricultural productivity.

By applying and adopting agricultural innovations, farmers will be able to implement modern agricultural techniques on their farms, and it will help to increase their income levels. Undoubtedly, conventional knowledge and experiences are quite important. However, harmonizing this knowledge and modern agricultural technologies is very important in terms of the increase of agricultural productivity. 
Table 4 Parameter estimates of multinominal regression results

\begin{tabular}{|c|c|c|c|c|c|c|c|}
\hline \multicolumn{2}{|c|}{ Groups $^{\mathrm{a}}$} & $\mathrm{B}$ & Std. error & Wald & $\mathrm{df}$ & Sig. & $\operatorname{Exp}(\mathrm{B})$ \\
\hline \multirow{15}{*}{$\begin{array}{c}\text { I } \\
\text { don't apply } \\
\text { any } \\
\text { agricultural } \\
\text { innovations } \\
\text { (Y0) }\end{array}$} & Intercept & -0.619 & 3.739 & 0.027 & 1 & 0.869 & \\
\hline & AGE & 2.497 & 2.356 & 1.124 & 1 & 0.289 & 12.151 \\
\hline & EDU & -9.023 & 5.402 & 2.790 & 1 & $0.095 * *$ & 0.000 \\
\hline & EXPE & 3.830 & 3.178 & 1.452 & 1 & 0.228 & 46.061 \\
\hline & ANIM & -3.762 & 3.782 & 0.989 & 1 & 0.320 & 0.023 \\
\hline & MILK & 4.899 & 4.575 & 1.146 & 1 & 0.284 & 134.118 \\
\hline & REC & 4.899 & 4.575 & 1.146 & 1 & 0.284 & 134.118 \\
\hline & $\mathrm{MACH}$ & 7.155 & 3.826 & 3.497 & 1 & $0.061 * *$ & 1280.455 \\
\hline & FORA & -1.293 & 2.937 & 0.194 & 1 & 0.660 & 0.275 \\
\hline & SILA & -11.716 & 6.064 & 3.733 & 1 & $0.053 * *$ & $8.160 \mathrm{E}-6$ \\
\hline & $\mathrm{COOP}$ & -1.936 & 2.079 & 0.867 & 1 & 0.352 & 0.144 \\
\hline & MILA & 3.274 & 3.477 & 0.887 & 1 & 0.346 & 26.427 \\
\hline & BEEF & 9.537 & 5.515 & 2.991 & 1 & $0.084 * *$ & 13866.168 \\
\hline & INCO & -10.832 & 5.966 & 3.297 & 1 & $0.069 * *$ & $1.975 \mathrm{E}-5$ \\
\hline & AGRI & -5.825 & 4.236 & 1.891 & 1 & 0.169 & 0.003 \\
\hline \multirow{15}{*}{$\begin{array}{c}\text { I } \\
\text { apply } \\
\text { agricultural } \\
\text { innovations } \\
\text { (Y2) }\end{array}$} & Intercept & -4.208 & 2.704 & 2.422 & 1 & 0.120 & \\
\hline & AGE & -0.837 & 1.311 & 0.407 & 1 & 0.523 & 0.433 \\
\hline & EDU & 0.245 & 1.053 & 0.054 & 1 & 0.816 & 1.277 \\
\hline & EXPE & -1.413 & 0.920 & 2.358 & 1 & 0.125 & 0.243 \\
\hline & ANIM & 1.807 & 1.091 & 2.742 & 1 & $0.098 * *$ & 6.092 \\
\hline & MILK & -2.083 & 1.218 & 2.923 & 1 & $0.087 * *$ & 0.125 \\
\hline & REC & 0.520 & 0.717 & 0.527 & 1 & 0.468 & 1.682 \\
\hline & $\mathrm{MACH}$ & 0.805 & 1.185 & 0.462 & 1 & 0.497 & 2.237 \\
\hline & FORA & 2.925 & 1.359 & 4.632 & 1 & $0.031 *$ & 18.632 \\
\hline & SILA & 0.023 & 1.115 & 0.000 & 1 & 0.984 & 1.023 \\
\hline & $\mathrm{COOP}$ & 0.471 & 0.703 & 0.450 & 1 & 0.503 & 1.602 \\
\hline & MILA & 0.090 & 0.736 & 0.015 & 1 & 0.903 & 1.094 \\
\hline & BEEF & 1.793 & 0.787 & 5.187 & 1 & $0.023 *$ & 6.007 \\
\hline & INCO & 0.061 & 0.699 & 0.008 & 1 & 0.930 & 1.063 \\
\hline & AGRI & 0.822 & 0.902 & 0.832 & 1 & 0.362 & 2.276 \\
\hline
\end{tabular}

a. The reference category is $\mathrm{Y} 1$; * Significant at $\mathrm{P}<0.05$; ** Significant at $\mathrm{P}<0.10$

It was determined in the research that farmers generally take a positive attitude against the idea of adoption of agricultural innovations. Likewise, a considerable portion of the farmers answered the question 'Do you apply agricultural innovations?' as 'I apply agricultural innovations.' It was specified that a major portion of the farmers attended agricultural fairs (89\%). As it is known, agricultural fairs are very significant agriculture organizations that present the latest developments, technologies, new inputs and recent products to the farmers; and gather all partners of the sector. Farmers' participation rate to agricultural fairs can be interpreted as an important sign in terms of their willingness to learn about innovations and their application.

In the research, it was found that some innovations are adopted by the farmers (ear numbering of cows, milking machine usage, fodder crop production, maize production for silage, etc.) and some innovations are not sufficiently adopted (animal insurance, electronic animal identification system, automatic animal weighing system). It was observed in the study that farmers do their agricultural activities by considering their knowledge and experiences; they do not communicate through agricultural extension services. It was determined that farmers meet with workers of public extension services 3.7 times in a year.

As a conclusion of the statistical analysis done, it was determined that a one unit increase in the education level of farmers raised the likelihood of applying innovations after receiving positive opinion. Furthermore, it was found that a one unit increase in the number of milking animals increased the likelihood of farmers applying innovations.

By performing agricultural activities mostly in accordance with their knowledge and experiences, farmers are not able to harmonize conventional knowledge and scientific knowledge. Therefore, the causes of this situation must be first researched, and farmers must be provided access to scientific knowledge by giving importance to extension activities for dairy farming.

Extension programs must be prepared regarding innovations that have low application rates as determined in the research. Disincentive factors regarding the application of innovations in question must be appointed. 
Farmers must designate problems and needs in order to create good communication between extension services and farmers. Agricultural extension programs which are proper for the local conditions must be prepared.

Farmers must be informed about fairs, symposiums and conferences about dairy farming and farmers must be supported to attend to these activities.

\section{Acknowledgements}

I wish to thank all farmers that participated in my study.

\section{References}

Amlaku A, Sölkner J, Puskur R, Wurzinger M. 2012. The impact of social networks on dairy technology adoption: evidence from Northwest Ethiopia. International Journal of AgriScience, 2(11): 1062-1083.

Anandajayasekeram P, Puskur R, Zerfu E. 2009. Applying Innovation System Concept in Agricultural Research for Development: A Learning Module. International Livestock Research Institute Publication Unit, Addis Ababa, Ethiopia.

Anonymous 2014. Records of Milas Milk Producers Union, June. 2014.

Aksoy A, Külekçi M., Yavuz F. 2011. Analysis of the factors affecting the adoption of innovations in dairy farms in Erzurum Province, Turkey. African Journal of Agricultural Research, 6(13): 2966-2970.

Akudugu MA, Guo E, Dadzie SK. 2012. Adoption of modern agricultural production technologies by farm households in Ghana: What factors influence their decisions? Journal of Biology, Agriculture and Healthcare, 2(3): 1-13.

Bayaga A. 2010. Multinominal logistic regression: usage and application in risk analysis. Journal of Applied Quantitative Methods, 5 (2): 288-297.

Boz İ, Akbay C, Bas S, Budak DB. 2011. Adoption of innovations and best management practices among dairy farmers in the Eastern Mediterranean Region of Turkey. Journal of Animal and Veterinary Advances, 10(2): 251-261.

Çiçek H, Cevger Y, Tandoğan M. 2008. Socio-economic factors affecting the level of adoption of innovations in dairy cattle enterprises. Ankara University Faculty of Veterinary Journal, 55: 183-187.

Dehinenet G, Mekonnen H, Kidoido M, Ashenafi M, Bleich EG. 2014. Factors influencing adoption of dairy technology on small holder dairy farmers in selected zones of Amhara and Oromia National Regional States, Ethiopia. Discourse Journal of Agriculture and Food Sciences, 2(5): 126-135.

Greene WH. 2002. Econometric Analysis. 5th edition, Prentice Hall Upper Saddle River, New Jersey.

Halakatti SV, Kamaraddi V, Gowda, DSM. 2007. Determinants of adoption of dairy farming technologies by rural women under SGSY scheme. Karnataka J. Agric. Sci., 20(2): 323-325.
Howley P, Donoghue CO, Heanue K. 2012. Factors affecting farmers' adoption of agricultural innovations: a panel data analysis of the use of artificial insemination among dairy farmers in Ireland. Journal of Agricultural Science, 4(6):171179.

Jaisridhar P, Sankhala G, Kadian KS, Kumar S, Sangeetha S. 2013. Factors determining adoption of scientific dairy farming with special reference to farmer's call centre of Tamil Nadu. Pak. J. Agri. Sci., 50(4): 549-553.

Jera R, Ajayi OC. 2008. Logistic modeling of smallholder livestock farmers' adoption of tree-based fodder technology in Zimbabwe. Agrekon, 47 (3): 379-392.

Kaaya H, Bashaasha B, Mutetikka D. 2005. Determinants of utilisation of artificial insemination (AI) services among Ugandan dairy farmers. African Crop Science Conference Proceedings. Kampala, Uganda, 5 -9 December 2005. pp. 561567.

Khanal AR, Gillespie J. 2013. Adoption and productivity of breeding technologies: evidence from US dairy farms. AgBioForum, 16(1): 53-65.

Kebede Y, Gunjal K, Coffin, G. 1990. Adoption of new technologies in Ethiopian Agriculture: The Case of TeguletBulga District. Shoa Province. Agricultural Economics, 4 (1): 27-43.

Letha DG. 2013. Adoption of dairy farming technologies by livestock farmers. Indian Res. J. Ext. Edu., 13 (2):57-61.

Mburu LM, Wakhungu JW, Gitu KW. 2007. Determinants of smallholder dairy farmers' adoption of various milk marketing channels in Kenya highlands. Livestock Research for Rural Development, 19 (9), Erişim adresi: http://www.lrrd.org/lrrd19/9/mbur19134.htm [Erişim: 26.07.2016].

Mishra AK, Williams RP, Detre JD. 2009. Internet access and internet purchasing patterns of farm households. Agricultural and Resource Economics Review, 38(2): 240-257.

Newbold P. 1995. Statistics for Business and Economics. New Jersey. Prentice-Hall International.

Prokopy LS, Floress K, Klotthor-Weinkauf D, Baumgart-Getz A. 2008. Determinants of agricultural best management practice adoption: Evidence from the literature. Journal of Soil and Water Conservation, 63(5): 300-311.

Shahin ASAH. 2004. Adoption of innovations in smallholder buffalo dairy farms in the Menoufia Province in Egypt. Berlin. Verlag Dr. Köster, ISBN 3-89574-526-X.

Singha AK, Baruah MJ. 2012. Adoption behavior of dairy innovations by small farmers under different farming systems in Assam. Indian Res. J. Ext. Edu., 12 (3): 60-64.

Snapp S, Pound B. 2008. Agricultural Systems: Agroecology \& Rural Innovation for Development. 1st edition, Amsterdam. Elsevier. ISBN 978-0-12-372517-2.

Tebug SF, Chikagwa-Malunga S, Wiedemann S. 2012. On-farm evaluation of dairy farming innovations uptake in northern Malawi. Livestock Research for Rural Development, 24(5): 1-9.

Quddus MA. 2012. Adoption of dairy farming technologies by small farm holders: practices and constraints. Bangladesh Journal of Animal Science, 41 (2): 124-135.

World Bank 2011. Agricultural Innovation Innovations Systems an Investment Sourcebook. Washington DC. The World Bank. ISBN 978-0-8213-8944-7. 